\title{
Correction to: The Potential Effect of the Psychiatric Clerkship and Contact-Based Hypothesis on Explicit and Implicit Stigmatizing Attitudes of Canadian Medical Students Towards Mental Illness
}

Anish Arora ${ }^{1} \cdot$ Harman S. Sandhu ${ }^{2} \cdot$ Jennifer Brasch ${ }^{2}$

Published online: 11 September 2019

(C) Academic Psychiatry 2019

Correction to: Academic Psychiatry

https://doi.org/10.1007/s40596-019-01090-2

The authors would like to correct the footnote of Table 2. It should read:

*Significant at the $p<0.05$ level

Publisher's Note Springer Nature remains neutral with regard to jurisdictional claims in published maps and institutional affiliations.

The online version of the original article can be found at https://oi.org/ 10.1007/s40596-019-01090-2

Anish Arora

anish.arora@mail.mcgill.ca

1 McGill University, Montreal, Quebec, Canada

2 McMaster University, Hamilton, Ontario, Canada 